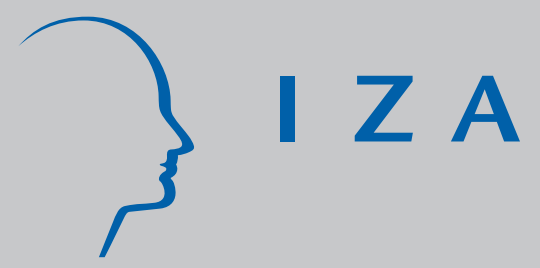

IZA DP No. 44

Overtime Working in an Unregulated

Labour Market

David N. F. Bell

Robert A. Hart

J une 1999 


\title{
Overtime Working in an Unregulated Labour Market
}

\author{
David N. F. Bell \\ Robert A. Hart \\ Discussion Paper No. 44 \\ June 1999 \\ IZA \\ P.O. Box 7240 \\ D-53072 Bonn \\ Germany \\ Tel.: +49-228-3894-0 \\ Fax: +49-228-3894-210 \\ Email: iza@iza.org
}

This Discussion Paper is issued within the framework of IZA's research area Mobility and Flexibility of Labor Markets. Any opinions expressed here are those of the author(s) and not those of the institute. Research disseminated by IZA may include views on policy, but the institute itself takes no institutional policy positions.

The Institute for the Study of Labor (IZA) in Bonn is a local and virtual international research center and a place of communication between science, politics and business. IZA is an independent, nonprofit limited liability company (Gesellschaft mit beschränkter Haftung) supported by the Deutsche Post AG. The center is associated with the University of Bonn and offers a stimulating research environment through its research networks, research support, and visitors and doctoral programs. IZA engages in (i) original and internationally competitive research in all fields of labor economics, (ii) development of policy concepts, and (iii) dissemination of research results and concepts to the interested public. The current research program deals with (1) mobility and flexibility of labor markets, (2) internationalization of labor markets and European integration, (3) the welfare state and labor markets, (4) labor markets in transition, (5) the future of work, and (6) general labor economics.

IZA Discussion Papers often represent preliminary work and are circulated to encourage discussion. Citation of such a paper should account for its provisional character. 


\section{ABSTRACT}

\section{Overtime Working in an Unregulated Labour Market}

Using individual-level data on male non-managerial workers from the 1996 British New Earnings Survey, we estimate overtime hours and average premium pay equations. Among other issues, four broad questions are of central importance. (a) What are the impacts of straight-time pay and hours on overtime pay and hours? (b) Is premium pay positively related to the length of weekly overtime? (c) What is the influence of collective bargaining coverage on overtime pay and hours? (d) Does overtime working serve significantly to alter wage earnings differentials between covered and uncovered workers? These and other issues are discussed comparatively in relation to unregulated British overtime working practices and to the United States were overtime is subject to mandatory rules.

JEL Classification: J33, J38

Keywords: Overtime, collective bargaining, labor market regulation

Robert A. Hart

Department of Economics

University of Stirling

Stirling, FK9 4LA

Scotland, U.K.

Tel: +441786467486

Fax: +44 1786467469

e-mail: r.a.hart@stir.ac.uk

\footnotetext{
* Financial support for this project was provided by the Faculty of Management, University of Stirling. We thank Robin Ruffell and Steve Trejo for useful comments. We benefited from seminar/workshop sessions at the Institute for Labor Studies (IZA), Bonn and at the universities of Hannover, Lancaster, Stirling and St. Andrews. We are grateful to Elizabeth Roberts for research assistance and to the Department for Education and Employment for access to the NES data set. The views expressed in the paper do not necessarily reflect those of the Department for Education and Employment.
} 


\section{Introduction}

Using individual-level data on male non-managerial workers from the 1996 British New Earnings Survey, we estimate overtime hours and average overtime premium pay equations. We note that, despite the importance of the overtime premium in the evaluation of the marginal cost of the labour input, this is the first study to provide detailed micro evidence on this variable. Overtime working in the British labour market is essentially an unregulated activity. Where possible, we compare and contrast our key results with equivalent findings in the United States where overtime is subject to mandatory rules. Among other issues, four broad sets of questions are of central importance.

(a)What are the impacts of straight-time pay and hours on overtime pay and hours?

(b) How does the premium pay schedule relate to the length of weekly overtime?

(c)What is the influence of collective bargaining coverage on overtime pay and hours?

(d)Does overtime working serve significantly to alter wage earnings differentials between covered and uncovered workers?

The marginal cost of labour plays a key role in labour market economics. Changes in marginal cost can occur at the extensive margin as a result of varying the number of workers, or at the intensive margin through changes in labour utilisation rates. In this latter respect, marginal cost is partly determined by the relationship between hours of work and hourly pay. Where workers are paid for the hours of labour they supply rather than directly for the amount of output they produce, this relationship for many workers is encapsulated in the overtime premium function (e.g. Sharpiro, 1986; Bils, 1987; Calmfors and Hoel, 1988; Hart and Ruffell, 1993). This shows the premium which workers can expect to achieve for the incremental hour of labour supply above 
straight-time hourly rates. The premium is frequently cited in theoretical discussions of the supply and demand for labour at the micro level (for respective surveys, see Killingsworth (1983) and Hamermesh (1993)). Where leisure is a normal good, a convex premium function increases the balance of the substitution effect relative to income effects and thus increases labour supply for a given cost outlay.

In much of the existing literature, the premium is treated as exogenous. One reason for this is that overtime in some countries is compensated at relatively high minimum mandatory rates. This is especially the case in the United States where workers covered by the Fair Labour Standards Act (FLSA) must be recompensed at 1.5 times straight-time hourly rates for weekly hours in excess of $40 .^{2}$ In most major industrialised countries, however, minimum premium rates are either lower than in the US or no pay rules are imposed outside of individual collective bargaining agreements. In these latter cases, the question arises as to whether overtime premium payments vary with average per-period overtime hours. We study this and other overtime issues with respect to the British labour market. This is one of the least regulated of the European markets as far as working time is concerned ${ }^{3}$ and one where extensive

\footnotetext{
2 Although see Trejo (1993) whose study is partially motivated by the fact that the coverage of and compliance with FLSA regulations are far from complete.

${ }^{3}$ Generally, the number of hours of overtime is agreed between the employee and the employer and set out in the employee's written statement of terms and conditions of employment. There is no legal requirement that overtime worked should receive a premium rate for hours worked in excess of straight-time hours. In October 1998, the British Government adopted the European Working Time Directive which limits the length of working time for each seven day period to 48 hours. Other areas of the Directive - such as provisions for minimum rest periods and night shifts - may also impinge on overtime working. Even under the Directive, however, employers and workers are free to reach agreements to work longer than the seven day limit and it remains to be seen if the Directive will significantly alter average weekly hours. In any event, the data used in this study refer to a period before the Directive came into operation.
} 
weekly overtime is undertaken by significant numbers of workers (Bell and Hart, 1998).

In both theoretical and empirical work, it is commonly assumed that a single premium rate of pay applies to all weekly overtime working. This is a fundamental assumption since, for example, key employment outcomes hinge on it. Yet, it may not be a valid approximation to reality, especially where overtime compensation is unregulated. We might expect a priori that premium rates would rise with the length of overtime hours. If hours are pro-cyclical, for example, firms may only be able to induce additional overtime during upturns in economic activity by paying higher marginal rates. If average overtime pay rises in average weekly hours, then theoretical outcomes in workers-hours models can be greatly altered (Santamäki-Vuori, 1986; Hart and Ruffell, 1992). Relatively little empirical work has been undertaken into this issue. One exception is the British study by Hart and Ruffell (1993) into the shapes of the overtime premium function based on industrial data at the 2-, 3- and 4- digit level.

A major policy issue in Europe concerns the effects of collective bargaining on straight-time and overtime hours. In general, unions have been successful in reducing the length of weekly straight-time hours. One rationale for this observation is that unions are interested in worksharing in the sense of reducing the hours of those with jobs in order to create more employment opportunities for the unemployed. In our empirical work, however, we obtain strong evidence that collective bargaining in Britain is associated with longer overtime hours. Where overtime is worked ceteris paribus, this would suggest that those covered by collective agreements would gain over and above straight-time pay differentials - relative to uncovered workers since a higher proportion of total weekly hours are compensated at premium rates. But this 
begs the question of whether covered workers achieve the same, or better, premium rates than their uncovered counterparts. We present here the first ever evidence on this issue. As a related topic of interest, we also investigate whether or not overtime covered/ uncovered pay differentials serve significantly to influence covered/ uncovered wage earnings differentials.

Estimation is based on Europe's richest source of statistics on working time and employment, the British New Earnings Survey (NES). This provides individual-level data obtained from employers' payroll tax records. We concentrate on non-managerial male workers for the year 1996, with a sample size of twenty-six thousand workers. ${ }^{4}$ In line with other studies (e.g. Trejo, 1993, Bell and Hart, 1998), these data allow us to study economic influences on overtime hours. The main comparative advantage of the data, however, is that they also provide breakdowns of each component part of the average hourly wage rate and thereby facilitate calculation of each individual's average rate of overtime premium pay. Most comparable data sets do not permit sufficient disaggregation to permit measurement of the premium. We are able, therefore, to investigate economic influences on both overtime hours and premium pay to an equal degree.

\section{The Shape of the Overtime Premium Schedule}

Let a denote hourly earnings (i.e. the hourly wage rate inclusive of overtime): thus,

$\mathrm{a}=\frac{\overline{\mathrm{h}} \mathrm{w}+\mathrm{pwv}}{\mathrm{h}}$

\footnotetext{
${ }^{4}$ About 40 percent of total male workers and 20 percent of females work overtime in the NES sample. Of the non-managerial males studied here, 62 percent worked overtime.
} 
where $\mathrm{h}$ is total weekly hours worked, $\overline{\mathrm{h}}$ is straight-time weekly hours and $\mathrm{w}$ is the straight-time hourly wage (i.e. the hourly wage exclusive of overtime), and $v=(h-\bar{h})$ is overtime hours. It follows that the average overtime premium, $\mathrm{p}$, is given by

$$
\mathrm{p}=\frac{(\mathrm{a} / \mathrm{w}) \mathrm{h}-\overline{\mathrm{h}}}{\mathrm{v}}
$$

There is some British evidence (Brown et al., 1986) that the weekly payments schedule facing most individual overtime workers consists of either a single premium rate for all overtime hours worked or a rising step function. ${ }^{5}$ Suppose that there are $\mathrm{n}$ steps. Then the relationship between the marginal and average premium is given by

$$
\mathrm{p}=\left(\sum_{\mathrm{i}=1}^{\mathrm{n}} \mathrm{k}_{\mathrm{i}} \mathrm{v}_{\mathrm{i}}\right) /\left(\sum_{\mathrm{i}=1}^{\mathrm{n}} \mathrm{v}_{\mathrm{i}}\right)
$$

where $\mathrm{k}_{\mathrm{i}}$ is the $\mathrm{i}^{\text {th }}$ marginal overtime premium and $\mathrm{v}_{\mathrm{i}}$ is the number of overtime hours worked in the $i^{\text {th }}$ segment of total overtime hours. Given that $\mathrm{k}_{1} \geq 1$ and $\mathrm{k}_{1}<\mathrm{k}_{2}<\ldots<\mathrm{k}_{\mathrm{n}}$ we generate the shapes of premium schedule illustrated in Figure 1.

a) If the worker works $\mathrm{v}_{1}\left(=\mathrm{h}_{1}-\overline{\mathrm{h}}\right)$ overtime and receives a single premium, $\mathrm{k}_{1}$ then the average wage rate in (1) is $\mathrm{a}=\left(\mathrm{wh}+\mathrm{wk}_{1} \mathrm{v}_{1}\right) / \mathrm{h}_{1}$ and $\mathrm{p}=\mathrm{k}_{1}$ in (3), or the average equals the marginal overtime premium. This is depicted in Figure 1 as the

\footnotetext{
${ }^{5}$ This derives from a detailed study of 5000 British workers carried out in 1980 . The study revealed that the shapes of individuals' overtime premium schedules are varied. Some workers receive a single premium for all overtime hours worked. Others receive discrete rises in the marginal premium as the length of the working day/week increases. Far less common are payments schemes whereby workers receive less than the straight-time rate for the first hour of overtime. In general, an individual's marginal overtime premium can be expected to be either a constant or a rising stepfunction of overtime hours. More recent evidence on 40 individual company agreements on overtime payments schedules in the manufacturing and service sectors (Income Data Services, 1997) reveals that, typically overtime is recompensed at oneand-a-half time the straight time rate on Mondays to Fridays and at double the rate at the weekend. But other more complicated weekly gradations occur; for example Claas UK (agricultural harvesting machinery) pay at a premium rate of time-and-aquarter for the first 7.5 hours overtime, time-and-a-half thereafter, and a double rate on Sundays.
} 
first step of the schedule, with the marginal and average overtime wage along a-b given by $w_{1}$.

Figure 1: Marginal and Average Overtime Premia

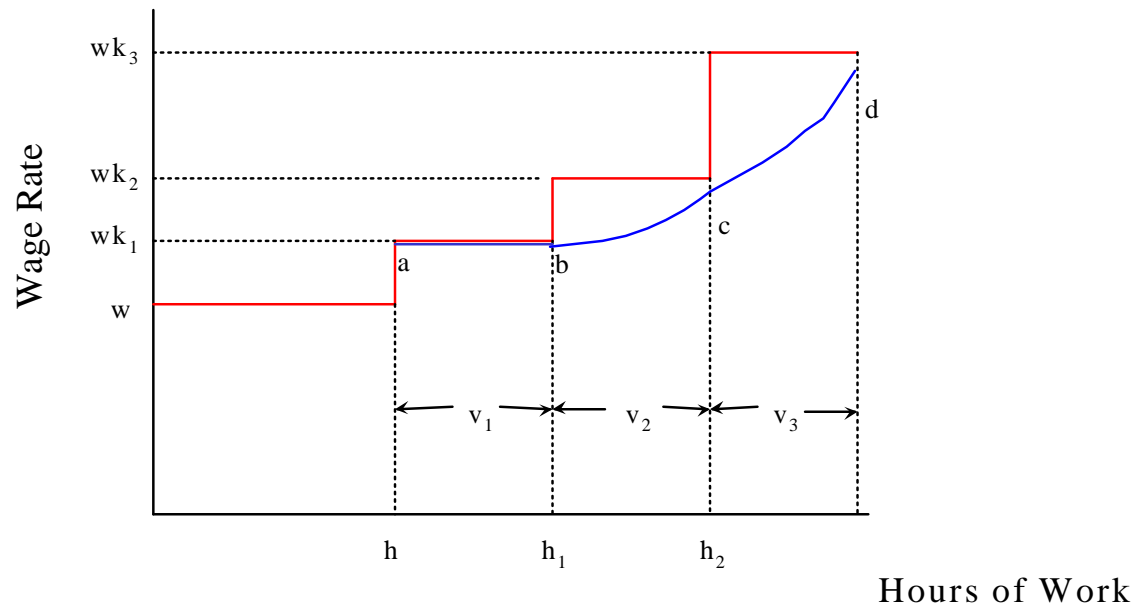

b) If a worker works $\mathrm{v}_{1}$ overtime at premium $\mathrm{k}_{1}$ and $\mathrm{v}_{2}\left(=\mathrm{h}_{2}-\mathrm{h}_{1}\right)$ at premium $\mathrm{k}_{2}$, with $\mathrm{k}_{2}>\mathrm{k}_{1}$, then $\mathrm{a}=\left(\mathrm{w} \overline{\mathrm{h}}+\mathrm{wk}_{1} \mathrm{v}_{1}+\mathrm{wk}_{2} \mathrm{v}_{2}\right) / \mathrm{h}_{2} \quad$ and $\mathrm{p}=\left(\mathrm{k}_{1} \mathrm{v}_{1}+\mathrm{k}_{2} \mathrm{v}_{2}\right) /\left(\mathrm{v}_{1}+\mathrm{v}_{2}\right)$. As depicted by the curve b-c in Figure 1, the average premium rises in overtime hours. The rate of increase is determined by two factors; first, the relative length of $v_{2}$ compared to $v_{1}$ and, second, the relative size of the overtime premium $\mathrm{k}_{2}$ compared to $\mathrm{k}_{1}$.

c) Extending to a three-step function, with successively rising premium rates, we have $\mathrm{p}=\left(\mathrm{k}_{1} \mathrm{v}_{1}+\mathrm{k}_{2} \mathrm{v}_{2}+\mathrm{k}_{3} \mathrm{v}_{3}\right) /\left(\mathrm{v}_{1}+\mathrm{v}_{2}+\mathrm{v}_{3}\right)$. As in $\left.\mathrm{b}\right)$, the average premium rises in overtime hours and depends on the relative sizes of the v's and the k's. It is clear that connecting points $\mathrm{b}, \mathrm{c}$ and $\mathrm{d}$ in Figure 1 might involve a complicated non-linear relationship between average premium pay and overtime hours. ${ }^{6}$

\footnotetext{
${ }^{6}$ Of course, this process may extend to three or more steps.
} 
If non-linear premium functions are commonly observed then this has major consequences for related theory and policy. This can be illustrated with respect to workers-hours demand models. ${ }^{7} \quad$ Typically, such models incorporate a homogeneous workforce, with each worker working the same per-period hours and facing a one-step premium schedule as in case a). For European labour market economists, such models have been used extensively to analyze the employment implications of mandatory cuts in weekly straight-time hours (e.g. Calmfors and Hoel, 1988). In recent times, such policy intervention has played an important role in countries like France, Germany and Italy in their efforts to reduce high and persistent unemployment. In general, however, economists have been very skeptical about this policy approach. Suppose the firm employs overtime hours in equilibrium. The "standard" model, incorporating a single premium step-function, predicts that a cut in hours increases marginal cost of employing a new worker while leaving the marginal cost of hours unchanged. Therefore, the firm substitutes more overtime working for fewer workers, an outcome which runs counter to the intended employment policy goal. But what if the premium rises in overtime hours? Then, straight-time hours reductions increase the cost of labour input on both intensive and extensive margins and worker-hours substitution is ambiguous. Depending on the relative shapes of marginal cost schedules on the two labour margins, new employment may be encouraged in this latter event. ${ }^{8}$

${ }^{7}$ For a general discussion of these models, see Ehrenberg (1971) and Hamermesh (1993). We should add that the basic idea discussed here in relation to simple labour demand analysis is an issue that arises in more general wage contract models in which the extensive and intensive labour margins are distinguished.

8 For formal developments with respect to the problem under discussion, see Santamäki-Vuori (1986) and Hart and Ruffell (1992). 


\section{Background Statistics}

The British NES provides data on individual workers, based on establishment records during a given week in April. We concentrate attention on full-time non-managerial male workers in $1996 .^{9} \quad$ Since European working time debates have been closely associated with collective bargaining, we highlight this issue in our empirics. The NES covered 103 collective agreements in 1996, entering a code for a collective agreement if it affects workers' pay and conditions either directly or indirectly. Twenty-two per cent of our sample are covered by such agreements. "Covered by a collective bargaining agreement" is a somewhat narrower definition than "belonging to a union"

${ }^{10}$ but, if anything, it is more apposite for present purposes. All major industries are comprised of a mix of covered/uncovered firms. ${ }^{11}$

Table 1 provides statistics of the key variables in respect of all workers and those covered by a collective agreement. Weekly overtime hours in Britain are the highest in

9 Full-time males are defined in the data as those who work at least 30 hours per week. We exclude males in professional and managerial occupations; in general, overtime is not explicitly remunerated for these job categories. We excluded a few individuals who were recorded as having a premium greater than 10 times the straight-time rate. Also we excluded individuals who were reported as having a premium less than unity (i.e. whose overtime hours were paid at a rate below the straight time rate). There were 2355 such individuals. As a safeguard, we repeated all calculations including this group obtaining no changes to our key findings.

${ }^{10}$ Compared to 21 percent collective bargaining coverage in our sample, the British Labour Force Survey reveals that in 199630 per cent of non-managerial male workers belonged to a union.

11 There are no cases of monopoly unions at industry level. There are several large pockets of unionism in the public sector but, in general, no major domination at industry level. In transport, for example, rail transport is dominated by workers covered by agreements but this competes with road transport, a much bigger sector, where the majority of workers are not covered. 
Europe $^{12}$, averaging 8.7 hours for workers working overtime in our total sample. The average overtime premium for these workers is 1.4 times the straight-time rate. Average straight-time hourly wages and hours do not differ as between overtime and total workers. For covered workers, both overtime hours and the average premium are slightly lower than those of total workers. Covered workers, both total and those working overtime, enjoy a straight-time wage rate about thirteen percent higher than the average for all workers.

\section{Table 1}

Wages, overtime premium and weekly hours: non-managerial males, 1996

\begin{tabular}{|c|c|c|c|c|}
\hline & \multicolumn{2}{|c|}{ All workers } & \multicolumn{2}{|c|}{$\begin{array}{l}\text { Covered by Collective } \\
\text { Agreements }\end{array}$} \\
\hline & Total & $\begin{array}{l}\text { Working } \\
\text { overtime }\end{array}$ & Total & $\begin{array}{l}\text { Working } \\
\text { overtime }\end{array}$ \\
\hline Hourly straight-time wage rate $(£)$ & $\begin{array}{l}6.7 \\
(2.5)^{*}\end{array}$ & $\begin{array}{l}6.6 \\
(2.3)\end{array}$ & $\begin{array}{l}7.6 \\
(2.7)\end{array}$ & $\begin{array}{l}7.6 \\
(2.6)\end{array}$ \\
\hline Average overtime premium & - & $\begin{array}{l}1.39 \\
(0.42)\end{array}$ & - & $\begin{array}{l}1.31 \\
(0.29)\end{array}$ \\
\hline Weekly straight-time hours & $\begin{array}{l}39.0 \\
(3.7)\end{array}$ & $\begin{array}{l}38.9 \\
(3.1)\end{array}$ & $\begin{array}{l}38.2 \\
(2.4)\end{array}$ & $\begin{array}{l}38.3 \\
(2.5)\end{array}$ \\
\hline Weekly overtime hours & - & $\begin{array}{l}8.7 \\
(7.6) \\
\end{array}$ & - & $\begin{array}{l}8.1 \\
(7.6) \\
\end{array}$ \\
\hline Sample size & 24,621 & 15,231 & 5,153 & 3,306 \\
\hline
\end{tabular}

* standard deviations in parentheses

The (unconditional) shape of the average premium schedule is shown in Figure 2. Between 1 and 2 weekly hours of overtime, the average premium rises steeply to exceed 1.4 times the straight time rate and then settles to maintain a more or less constant rate of just under 1.4 for all weekly overtime hours up to 25 . Interestingly,

\footnotetext{
${ }^{12}$ For example, they are roughly twice those of Germany. Bell et al. (1999) provide complete comparative data on working time in Britain and Germany using matched data in 1993.
} 
as shown in Figure 3, the straight-time weekly wage declines in overtime hours: lower paid workers work more overtime. By contrast, as revealed in Figure 4, weekly wage earnings rise monotonically in overtime hours. Therefore, as the week lengthens and given a zero premium-hours elasticity, the downward influence of the straight-time wage on weekly earnings is more than offset by the rise in weekly overtime hours.

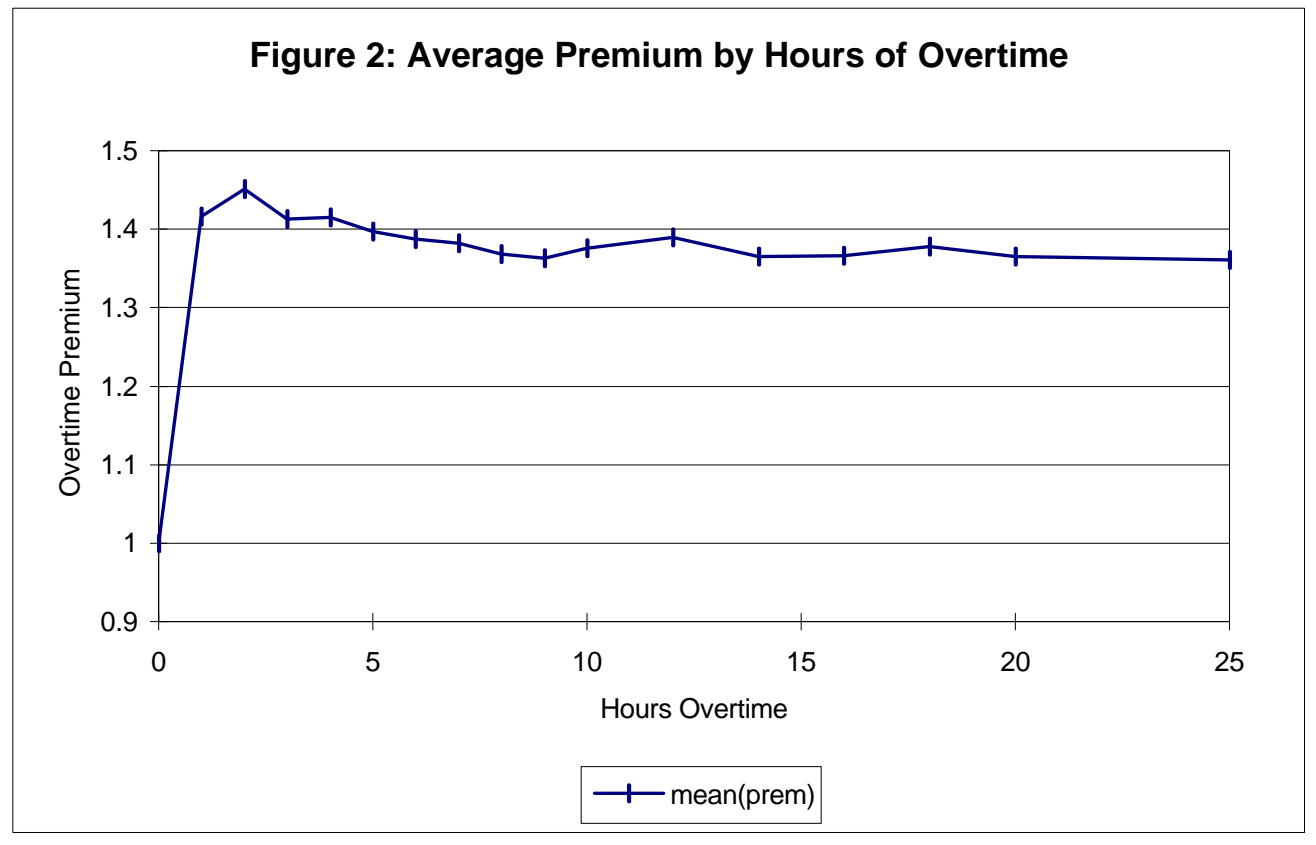

Pursuing the covered/uncovered dichotomy, Figure 5 shows the cumulative frequencies of length of weekly overtime hours in the NES sample week. It reveals very similar distributions for the two groups. The key feature of Figure 5 for present purposes, however, is that it reveals that extensive overtime working is not uncommon (see also Bell and Hart, 1998). For covered(uncovered) groups, 35(38) per cent of the samples worked 5 or more weekly overtime hours, 18(20) per cent 10 or more, 9(9) per cent 16 or more, and 5(5) per cent 20 or more. Evidence of significant overtime working over a wide band of weekly overtime hours serves to underpin the importance of investigating whether marginal increases in overtime hours are achieved at 
increasing marginal cost. In other words, after conditioning for economic and other control variables, does the overtime premium rise in weekly overtime hours?
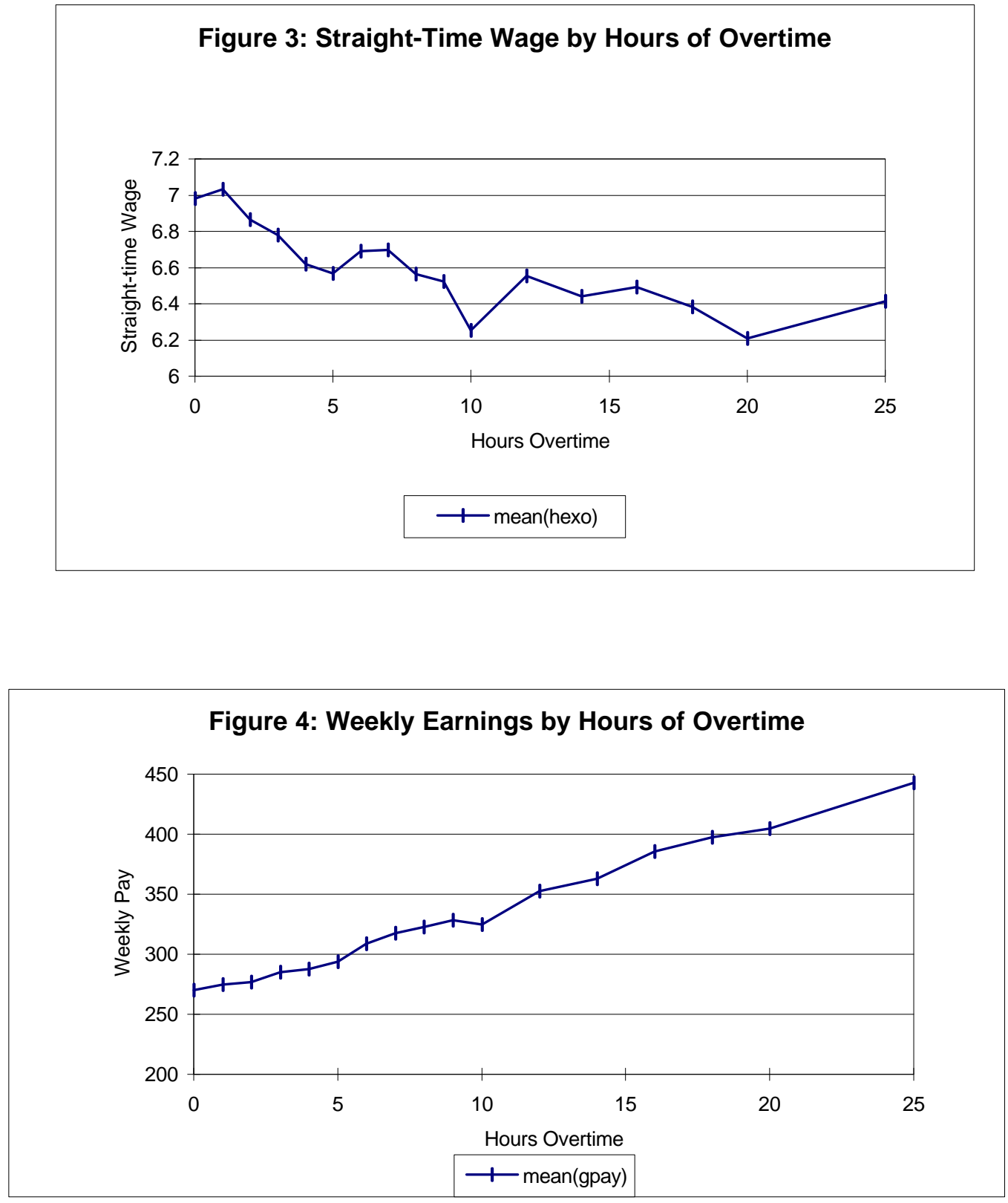


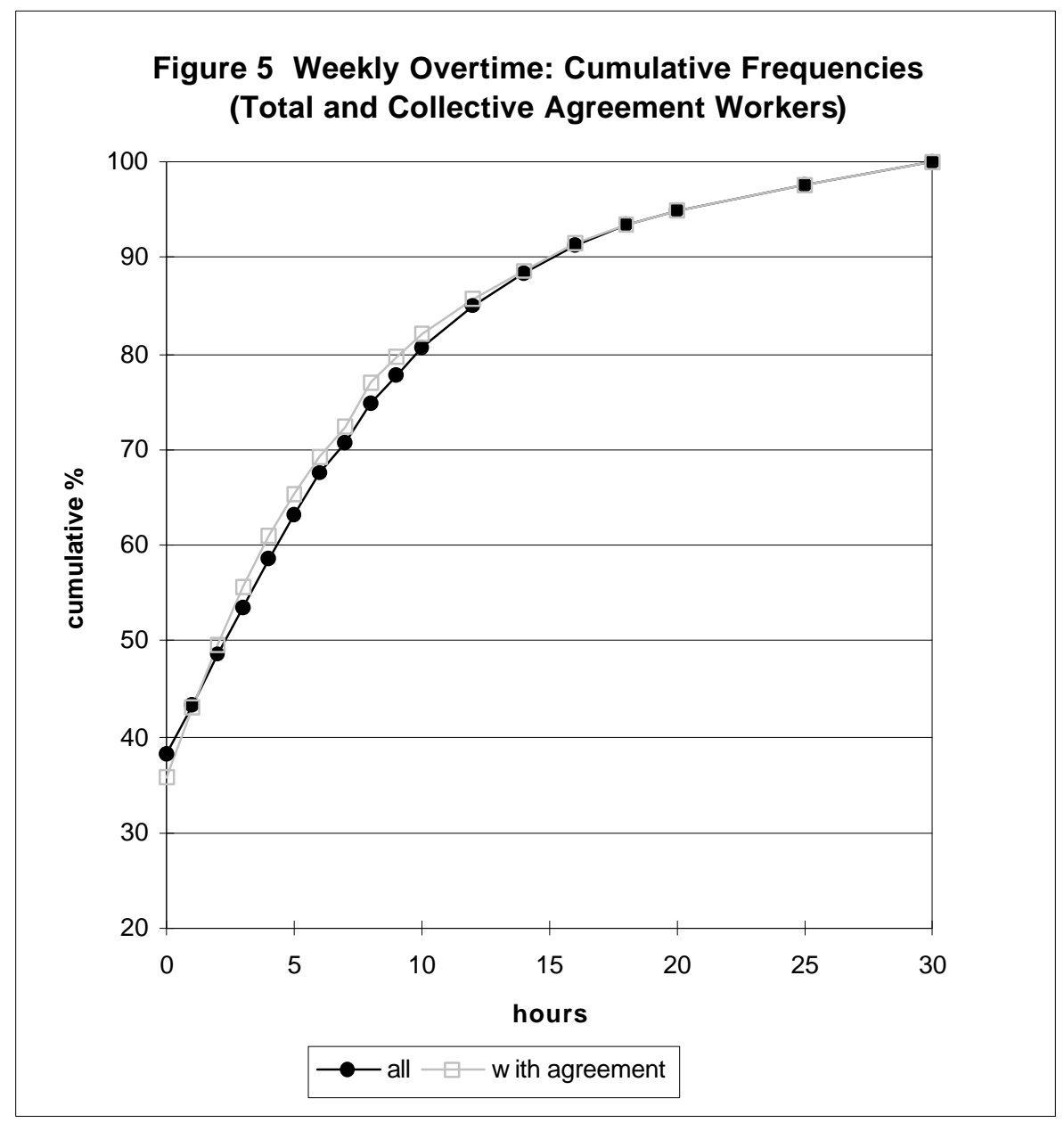

\section{Estimation}

In the following section, we present results for three types of estimating equations, describing (i) the incidence of overtime working, (ii) the number of weekly overtime hours worked, and (iii) the average overtime premium.

The incidence of overtime working is examined via a probit model in which the dependent variable takes the value of 0 if a worker does not work overtime in the survey week and 1 otherwise. Actual overtime hours worked and the average overtime premium rates, as defined in (2), are estimated by Tobit specifications. The hours Tobit equation takes the form 


$$
\begin{aligned}
\mathbf{o}_{\mathbf{i}} & =\mathbf{d}^{\prime} \mathbf{w}_{\mathbf{i}}+\varepsilon_{i} & & \text { if } \mathbf{d}^{\prime} \mathbf{w}_{\mathbf{i}}+\varepsilon_{i}>0 \\
& =0 & & \text { if } \mathbf{d}^{\prime} \mathbf{w}_{\mathbf{i}}+\varepsilon_{i} \leq 0
\end{aligned}
$$

where o stands for weekly overtime hours with respect to individual $\mathrm{i}, \mathbf{w}_{\mathbf{i}}$ is a vector of explanatory variables, $\mathbf{d}$ is a vector of coefficients, $\varepsilon_{\mathrm{i}}$ is an error term distributed with mean 0 and variance $\sigma_{\varepsilon}{ }^{2}$. The premium Tobit equation is given by

$$
\begin{aligned}
\mathbf{p}_{\mathbf{i}} & =\mathbf{f}^{\prime} \mathbf{m}_{\mathbf{i}} & & \text { if } \mathbf{f}^{\prime} \mathbf{m}+\mu_{i}>1 \\
& =1 & & \text { if } \mathbf{f}^{\prime} \mathbf{m}+\mu_{i} \leq 1
\end{aligned}
$$

where $\mathrm{p}$ is the average overtime premium, $\mathbf{m}_{\mathbf{i}}$ is a vector of explanatory variables, $\mathbf{f}$ is a vector of coefficients, $\mu_{\mathrm{i}}$ is an error term distributed with mean 0 and variance $\sigma_{\mu}{ }^{2}$.

In the hours equation (4), the explanatory variables $\mathbf{w}$ cover the straight-time wage, straight-time weekly hours, collective bargaining coverage, age, public/private sector industry as well as occupation, industry and area dummies. Additionally, in the premium rate equation (5) we include in the vector $\mathbf{m}$ dummy variables defining numbers of weekly overtime hours worked. This latter approach was chosen to allow flexibility of functional form in the relationship between the premium and overtime hours (see Figure 1 and related discussion). Figure 6 shows how these dummies are likely to capture the shape of the underlying premium function. Note that, since each dummy represents an interval of time, its value will necessarily represent the average premium over that interval and thus will tend to underestimate the marginal value of an increasing premium function. 
Figure 6: Estimating the Overtime Premium

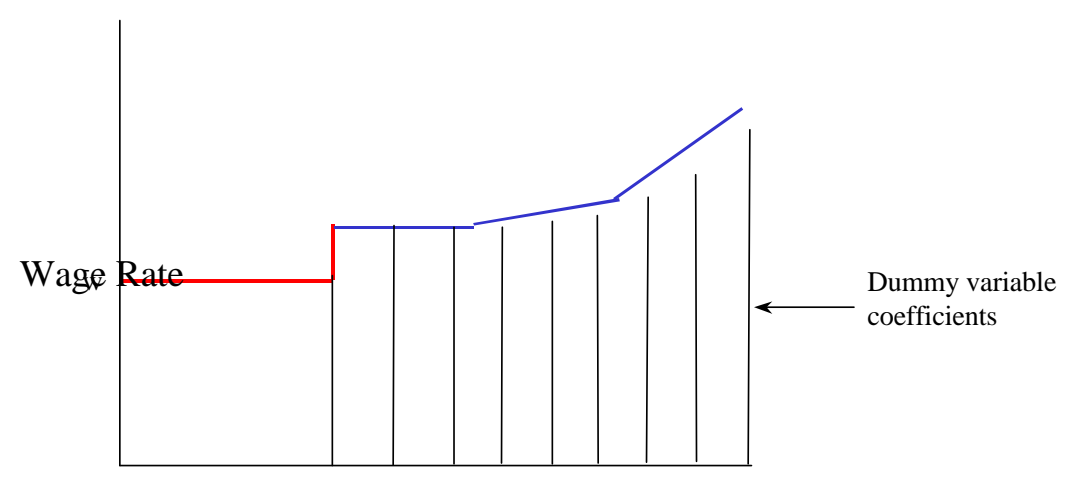

Hours of Work

\section{Results}

Results of the probit model of the incidence of overtime working are shown in the first two columns of Table 2. The straight-time wage exerts a negative influence on overtime incidence, a result consistent with an income effect. A similar role may also be attributed to straight-time weekly hours which are also negatively related to incidence. Collective bargaining is positively related to incidence; for an individual with the mean characteristics of the sample, being subject to a collective bargaining agreement increases the probability of working overtime by just over 4.5 percentage points. Central government workers have significantly reduced incidence. As for age effects, incidence rises with age up to the late 30's and during the 40's before declining.

The effects of these explanatory variables on the numbers of overtime hours worked are provided by the Tobit estimates shown in the last three columns in Table 2. The last two columns contain the decomposition proposed by McDonald and Moffitt 
Table 2

Determinants of Overtime Incidence and Hours

\begin{tabular}{|c|c|c|c|c|c|}
\hline \multirow[b]{3}{*}{ Variable } & \multicolumn{2}{|l|}{ Probit } & \multicolumn{3}{|l|}{ Tobit } \\
\hline & \multirow[b]{2}{*}{ Coefficient } & \multirow{2}{*}{$\begin{array}{l}\text { Effect on } \\
\operatorname{pr}\left(p_{h}>0\right)\end{array}$} & \multirow[b]{2}{*}{ Coefficient } & \multicolumn{2}{|l|}{ Effect on } \\
\hline & & & & $\operatorname{pr}\left(\mathrm{p}_{\mathrm{h}}>0\right)$ & $\mathrm{E}\left(\mathrm{p}_{\mathrm{h}} \mid \mathrm{p}_{\mathrm{h}}>0\right)$ \\
\hline S Straight-time hourly wage & $\begin{array}{l}-0.063^{*} \\
(0.004)\end{array}$ & (-0.024 & $\begin{array}{l}-0.631 * \\
(0.034)\end{array}$ & $\begin{array}{l}-0.024 \\
\end{array}$ & -0.274 \\
\hline Straight-time weekly hours & $\begin{array}{l}-0.031 * \\
(0.002)\end{array}$ & -0.012 & $\begin{array}{l}-0.202 * \\
(0.022)\end{array}$ & -0.008 & -0.087 \\
\hline Collective agreement & $\begin{array}{l}0.118 * \\
(0.028)\end{array}$ & 0.045 & $\begin{array}{l}1.160 * \\
(0.228)\end{array}$ & 0.045 & 0.503 \\
\hline Public corporation & $\begin{array}{l}0.040 \\
(0.048)\end{array}$ & 0.015 & $\begin{array}{l}-0.291 \\
(0.385)\end{array}$ & -0.011 & -0.126 \\
\hline Central government & $\begin{array}{l}-0.319 * \\
(0.050)\end{array}$ & -0.121 & $\begin{array}{l}-3.007^{*} \\
(0.445)\end{array}$ & -0.116 & -1.303 \\
\hline Local government & $\begin{array}{l}-0.032 \\
(0.043)\end{array}$ & -0.012 & $\begin{array}{l}-2.163^{*} \\
(0.367)\end{array}$ & -0.083 & -0.937 \\
\hline \multicolumn{6}{|l|}{ Age } \\
\hline Over 21 to 25 & $\begin{array}{l}0.234 * \\
(0.071)\end{array}$ & 0.089 & $\begin{array}{l}2.612 * \\
(0.617)\end{array}$ & 0.100 & 1.132 \\
\hline Over 25 to 30 & $\begin{array}{l}0.325^{*} \\
(0.070)\end{array}$ & 0.124 & $\begin{array}{l}4.189 * \\
(0.608)\end{array}$ & 0.161 & 1.815 \\
\hline Over 30 to 35 & $\begin{array}{l}0.408 * \\
(0.071)\end{array}$ & 0.155 & $\begin{array}{l}5.105^{*} \\
(0.611)\end{array}$ & 0.196 & 2.212 \\
\hline Over 35 to 40 & $\begin{array}{l}0.413^{*} \\
(0.072)\end{array}$ & 0.157 & $\begin{array}{l}5.200 * \\
(0.619)\end{array}$ & 0.200 & 2.253 \\
\hline Over 40 to 45 & $\begin{array}{l}0.367 * \\
(0.072)\end{array}$ & 0.140 & $\begin{array}{l}5.196^{*} \\
(0.624)\end{array}$ & 0.200 & 2.251 \\
\hline Over 45 to 50 & $\begin{array}{l}0.450 * \\
(0.072)\end{array}$ & 0.171 & $\begin{array}{l}5.790 * \\
(0.621)\end{array}$ & 0.222 & 2.509 \\
\hline Over 50 to 55 & $\begin{array}{l}0.315^{*} \\
(0.073)\end{array}$ & 0.120 & $\begin{array}{l}4.557^{*} \\
(0.630)\end{array}$ & 0.175 & 1.974 \\
\hline Over 55 to 60 & $\begin{array}{l}0.313^{*} \\
(0.074)\end{array}$ & 0.119 & $\begin{array}{l}4.270^{*} \\
(0.638)\end{array}$ & 0.164 & 1.850 \\
\hline Over 60 to 65 & $\begin{array}{l}0.087 \\
(0.078)\end{array}$ & 0.033 & $\begin{array}{l}2.719 * \\
(0.674)\end{array}$ & 0.104 & 1.178 \\
\hline Constant & $\begin{array}{l}1.529 * \\
(0.217)\end{array}$ & & $\begin{array}{l}12.320^{*} \\
(1.853)\end{array}$ & & \\
\hline 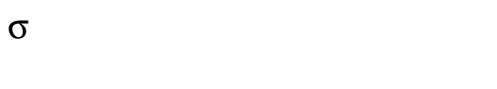 & & & $\begin{array}{l}9.933 * \\
(0.062)\end{array}$ & & \\
\hline $\begin{array}{l}\text { Occupational, industry, and area } \\
\text { dummies }\end{array}$ & Yes & & Yes & & \\
\hline Log likelihood & -15182.4 & & -61923.6 & & \\
\hline
\end{tabular}

NOTE. Standard errors are in parenthesis. Sample size is 24,029 workers.

* Statistically significant at the 0.01 level (two-tailed test).

** Statistically significant at the 0.05 level (two tailed test). 
(1980) this shows the effect of each explanatory variable on the probability of overtime incidence and on the expected number of overtime hours of those working overtime. Again, a strongly significant negative coefficient on the straight-time wage indicates an income effect. This result is corroborated by Bell and Hart (1999) on another British data set, the Labour Force Survey. It contrasts with Trejo (1993) for the US who finds a significant substitution effect of overtime hours on the straight-time wage. This contrasting US/British finding may well be indicative of differences between regulated and unregulated markets with respect to overtime working. An increase in the straighttime wage rate in the US may induce many workers to seek to forego leisure in order to take advantage of a relatively high mandatory overtime premium of 1.5. As before, straight-time weekly hours are negatively related to overtime. ${ }^{13}$

Collective agreements are significantly positively associated with overtime hours. This result is in line with the Labour Force Survey results of Bell and Hart (1999) where "belonging to a union" replaces the collective bargaining variable. Being covered by a collective bargaining agreement over pay and conditions increases by 4.5 percentage points the probability of an individual, with sample mean characteristics, working overtime. This finding is the same as the corresponding probit estimate. Coverage increases expected overtime working hours for those working overtime. For an individual with mean characteristics, coverage increases the conditional mean of weekly overtime by 30 minutes. The joint effect of coverage on overtime participation and overtime hours given participation is to increase unconditional mean overtime hours by just over 8 per cent. Of this latter figure, 70 per cent of the rise is accounted for by increased overtime among those workers working overtime.

Of the remaining explanatory variables in Table 2, both central and local government workers work significantly less weekly overtime hours compared to the private sector

\footnotetext{
${ }^{13}$ This result, when combined with the straight-time wage findings, may indicate an income effect on the supply-side; thus, low straight-time earnings induce more overtime working thereby producing an offsetting increase in total weekly earnings. It may also reflect a demand-side effect. For given output, lower straight-time hours increase the cost of labour on the extensive margin (i.e. employment) relative to the intensive margin (overtime working) and thereby lead the firm to substitute in the direction of longer average overtime hours (see Ehrenberg, 1971).
} 
(the excluded group). In line with the probit results on incidence, the number of overtime hours worked rises with age up to the late-40's before declining.

Equation (5) results with respect to the average overtime premium are shown in Table 3. ${ }^{14}$ The straight-time wage has a significant negative association with the premium. The previous straight-time wage effect on hours indicated an income effect; assuming leisure is a normal good, a typical worker reacts to an increase in the straight-time hourly rate-for-the-job by consuming more leisure. It would also appear that such a worker would also be willing to accept a lower premium attaching to that rate. Straight-time weekly hours are also negatively related to the premium. Statistically, at the chosen significance bounds, there is no coverage effect on the premium.

However, with a t-value of -1.44 , there is at least a question mark over whether collective bargaining serves to depress the premium, as earlier suggested by the (unconditional) averages in Table 1. We investigate this issue further in the following section. Workers in public corporations receive a significantly lower average premium.

14 Unlike the equivalent hours regressions in Table 2, age dummies are comprehensively insignificant in the premium equation and so they are dropped in the results shown in Table 3. 
Table 3 Determinants of the Average Overtime Premium: Tobit Estimates

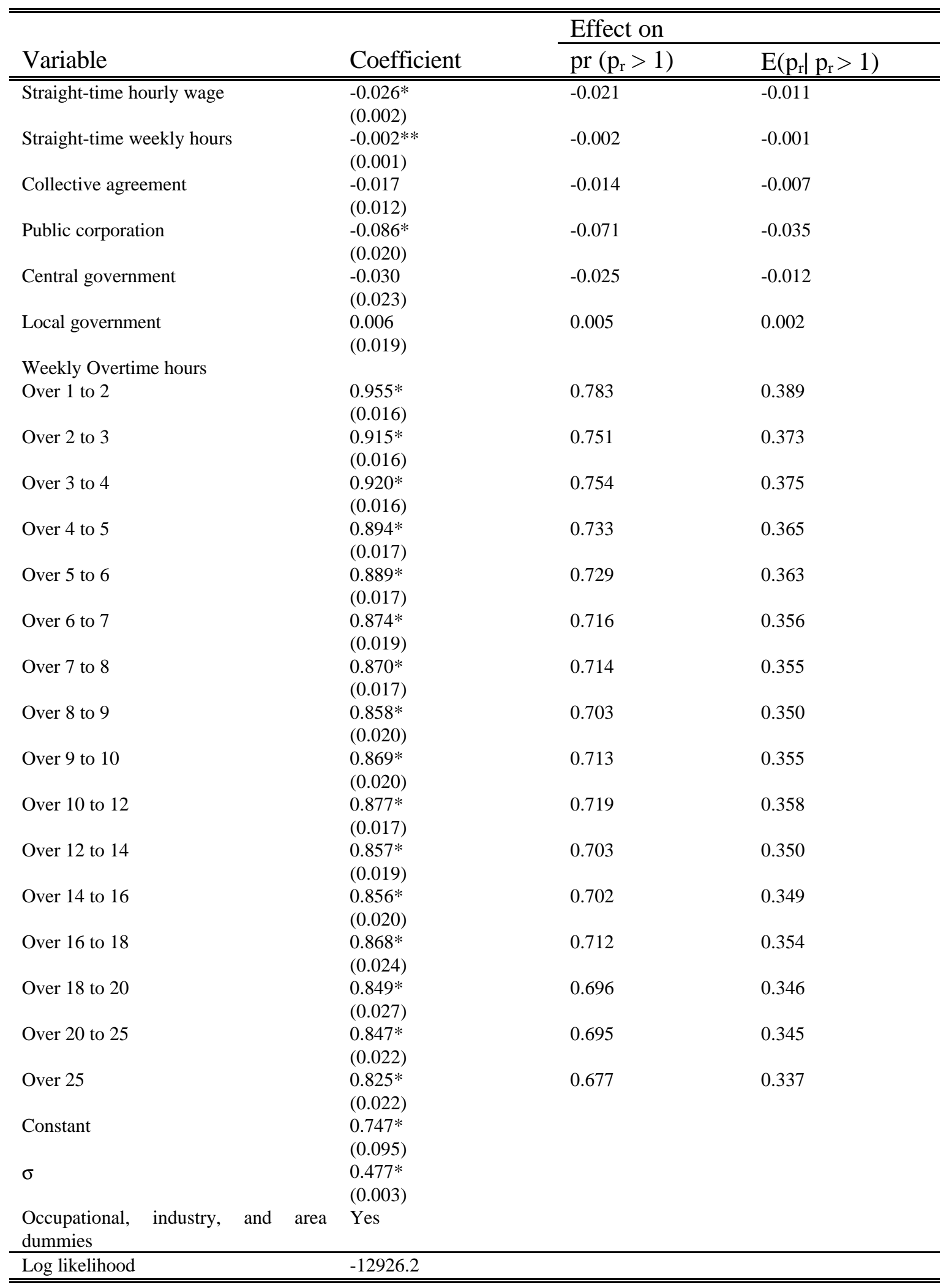

NOTE. As in Table 2. 
The central finding, however, is that the premium does not vary by length of weekly overtime hours. Conditioning with economic and other control variables does not support the shape of schedule generated in the discussion of Figure 1. Rather, it is highly supportive of the shape of schedule shown in Figure 2. The expected value of the premium conditional on the premium being greater than unity lies between 0.35 and 0.39 for weekly overtime hours between 2 and 14 . Over 14 weekly hours, the expected value drops below 0.35 , but only marginally. These results generally corroborate the earlier findings of Hart and Ruffell (1993) based on industry-level data. ${ }^{15}$

\section{Why is the average premium schedule flat?}

From a theoretical modelling perspective, estimating an overtime schedule with the simple shape illustrated in Figure 2 is reassuring to earlier researchers. The estimates support the predominant custom, practiced over a wide range of micro and macro papers, of incorporating a single premium rate for all overtime hours. Yet, from the viewpoint of simple supply-side labour market economics, the outcomes are somewhat puzzling. They suggest that workers who provide quite extensive numbers of weekly overtime hours do not receive higher marginal rates for significant erosion of leisure time. While a single rate might be expected to apply for all weekly hours of overtime in an economy like the U.S. - where an external body fixes the premium at a relatively high level - it is a much more surprising finding in an unregulated labour market.

We propose a very simple reason for these results. To avoid costly bargaining, monitoring and other transaction costs, companies and workers agree to simple

\footnotetext{
${ }^{15}$ The mean premium in the Hart and Ruffell is nearer 1.3 than 1.4 because their data set includes persons who received premiums below 1 . When these are included in the micro data here, we obtain extremely close estimates to the earlier work; again, the overtime schedule is flat.
} 
premium rate structures. This is true of the complete sample of 40 companies reported on by Incomes Data Services (1997), with many companies paying a rate of time-anda-half Mondays to Saturdays and double-time on Sundays. For most workers in these companies, the premium rate will be independent of their length of overtime working. In this case the expected value of the premium for given overtime hours would be a constant; that is, $\mathrm{E}[\mathrm{p} \mid \mathrm{o}]=\mathrm{k}$ (where $\mathrm{k}$ in our study is about 1.4).

This explanation is reasonably well supported by the data. We divided overtime workers in the sample into groups delineated by lengths of weekly overtime hours; these range from 1- 4 hours at the lower end of the spectrum to over 16 hours at the upper end. Then, we calculated the proportions within each of these groups working given bands of average overtime premiums; these latter range from an average rate of 1-1.2 to a rate of over 1.6. The results are shown in Figure 7. The proportions of overtime workers working at given average rates are similar across the hours groups. Between 27 and 31 percent of workers receive a premium in the $1-1.2$ interval $^{16}$ and between 23 and 28 in the 1.2 - 1.4 interval. The modal premium lies between $1.4-1.6$ for all groups, with between 30 and 35 of workers in this interval. The proportions of workers working a premium of 1.6 or more fall steeply for all hours categories, to 15 per cent or less for each group.

\footnotetext{
${ }^{16}$ In the complete sample, 6.4 percent of workers receive a premium equal to 1 ; that is, their hourly staight-time and overtime rates are the same.
} 
Figure 7: Proportions working overtime by overtime premium

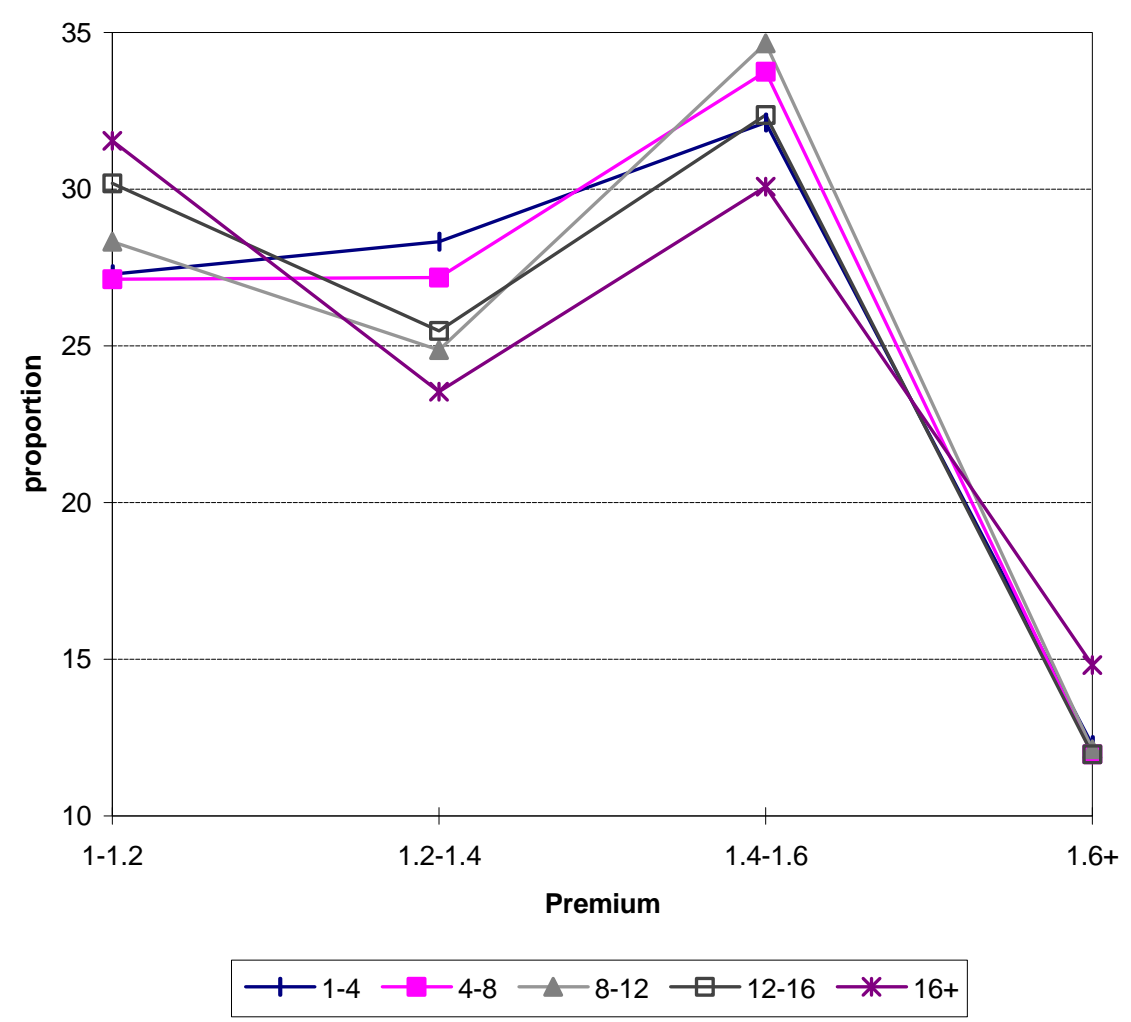

The similarity of the distributions across overtime hours is consistent with the foregoing explanation. It suggests that the size of the premium is predicated on the choice of firm. Since many firms appear to use simple overtime rules in which a single rate applies to a wide band of weekly overtime hours, the premium is effectively independent of the length of overtime working.

\section{Collective bargaining in regulated and unregulated markets}

Our collective bargaining results in Section 5 contrast sharply with those of Trejo (1993) with respect to the US. Trejo finds that union coverage serves to reduce both the incidence of overtime and the number of overtime hours worked by those who work overtime. In this latter respect, he finds that unions reduce the unconditional 
mean of weekly overtime per US worker in 1985 by 20 percent, with 78 percent of the effect resulting from reduced overtime incidence. This contrasts with a 8 percent increase in the unconditional mean in our study, with over 70 percent of the effect attributed to an increase in overtime hours of those working overtime. Trejo also finds that unions increase the probability of receiving a premium by 8 percent. In a US context, this means that unions serve to increase compliance with the overtime rules laid down under the FLSA regulations. Union members are also more prone to temporary layoffs in the US and so a rationale for overall union strategy regarding overtime working may be that of smoothing employment fluctuation through reduced overtime working while at the same time expanding union membership.

In Britain, the evidence is very strong that workers covered by a collective bargaining agreement succeed in reducing straight-time and raising overtime hours relative to uncovered workers. This runs counter to the argument that unions, as a form of worksharing, attempt to reduce straight-time hours in order to create additional jobs. The extent to which covered workers experience net gains in this strategy hinges crucially on the interpretation of the coefficient on collective bargaining in relation to the average premium (see Table 3). If, in fact, it represents a negative association then employers are able to offset the higher proportion of premium hours within total hours by paying a reduced premium. Alternatively, if it represents a zero effect then covered workers appear to be able to exert a considerable degree of market power.

A key question, therefore, is whether or not overtime pay serves significantly to affect covered/uncovered hourly wage earnings differentials. If it is found, for example, that hourly wage earnings differentials are greater than equivalent straight-time wage differentials then this would tend to suggest that the higher overtime hours worked by 
covered workers are not offset by a lower average premium among this group. To investigate this, we adopt the methodology presented by Trejo (1993). We derive the following decomposition of covered/uncovered average hourly earnings differentials ${ }^{17}$ :

$$
\ln \left(\frac{\mathrm{a}^{\mathrm{c}}}{\mathrm{a}^{\mathrm{n}}}\right)=\ln \left(\frac{\mathrm{w}^{\mathrm{c}}}{\mathrm{w}^{\mathrm{n}}}\right)+\left(\lambda^{c}-\lambda^{n}\right)+\frac{\lambda^{c} v^{c}\left(p^{c}-1\right)}{h^{c}}-\frac{\lambda^{n} v^{n}\left(p^{n}-1\right)}{h^{n}}
$$

where, in addition to previously denoted variables, a superscript "c" represents covered, " $n$ " uncovered and where $\lambda$ is the fraction of workers working overtime.

In (6), hourly wage earnings covered/uncovered differentials are affected by four factors: these are differences in (a) in straight-time hourly wages, (b) straight-time hours, (c) hours of overtime, (d) overtime pay. ${ }^{18}$ We know that $\mathrm{w}^{\mathrm{c}}>\mathrm{w}^{\mathrm{n}}$ and that $\mathrm{v}^{\mathrm{c}}\left(=\mathrm{h}^{\mathrm{c}}-\overline{\mathrm{h}}\right)>\mathrm{v}^{\mathrm{n}}$, which would act to increase the coverage differential. However, although there is statistical uncertainty as to the effects of coverage on the premium, there is evidence that $\mathrm{p}^{\mathrm{c}}<\mathrm{p}^{\mathrm{n}}$ which acts to reduce the coverage differential.

The regressions shown in Table 4 are intended to gauge the importance of overtime hours and pay on the differentials. It shows separate regressions of the (natural logs of) the hourly straight-time wage and hourly average earnings on a similar set of

${ }^{17}$ Recall from (1) that hourly earnings $\mathrm{a}=[\mathrm{wh}+\mathrm{pwv}] / \mathrm{h}$. If only straight-time hours are worked then $\mathrm{a}=\mathrm{w}$. Therefore, $\operatorname{lna}=\lambda \ln \{[\mathrm{w}(\overline{\mathrm{h}}+\mathrm{pv})] / \mathrm{h}\}+(1-\lambda) \operatorname{lnw}=$ $\operatorname{lnw}+\lambda\{1+[\mathrm{v}(\mathrm{p}-1)] /[\overline{\mathrm{h}}+\mathrm{v}]\}$, where $\lambda$ is the fraction of workers working overtime. Relative earnings differences in (6) are easily obtained by developing this latter expression.

${ }^{18}$ Clearly, in (6), overtime will have little impact on earnings differentials if (a) $v^{c}$ and $v^{n}$ are near zero or (b) if $p^{c}$ and $p^{n}$ are near unity. Otherwise, overtime effects will be small if components of overtime pay and hours that tend to increase the differential are largely offset by factors running in the opposite direction. 
explanatory variables to those in Table 2 with the addition of a variable that measures whether or not an individual has held a given job for over a year. ${ }^{19}$ The key finding is that the collective bargaining coverage variable displays almost identical coefficient sizes in the two equations which suggests that overtime (hours and pay) has little effect on the covered/uncovered earnings differentials. ${ }^{20}$ This tends to support the view that workers covered by collective agreements in Britain work shorter straight-time hours and longer overtime, thereby enhancing covered/uncovered wage differentials. This differential is offset, however, by the fact that they receive lower average overtime premiums. We note that in his U.S. study, Trejo (1993) also found little effect of overtime on union-nonunion differentials.

${ }^{19}$ This is the nearest proxy to "tenure" possible using the NES.

${ }^{20}$ Given well-known problems of endogeneity in respect of occupation variables in such wage equations, we also ran the regressions without occupational controls. While the collective bargaining coefficients rise somewhat - to 0.088 (straight-time wage equation) and 0.090 (earnings equation) - they remain very similar in the two equations. 
Table 4

Hourly Earnings Regressions

\begin{tabular}{|c|c|c|}
\hline Variable & $\begin{array}{l}\ln (\mathrm{w}) \\
\text { (Straight-time hourly } \\
\text { wage) }\end{array}$ & $\begin{array}{l}\ln (\mathrm{a}) \\
\text { (Hourly earnings) }\end{array}$ \\
\hline Collective agreement & $\begin{array}{l}0.081^{*} \\
(0.007)\end{array}$ & $\begin{array}{l}0.082^{*} \\
(0.007)\end{array}$ \\
\hline Public corporation & $\begin{array}{l}-0.081^{*} \\
(0.012)\end{array}$ & $\begin{array}{l}-0.066^{*} \\
(0.012)\end{array}$ \\
\hline Central government & $\begin{array}{l}0.044 * \\
(0.013)\end{array}$ & $\begin{array}{l}0.035^{*} \\
(0.013)\end{array}$ \\
\hline Local government & $\begin{array}{l}0.156^{*} \\
(0.011)\end{array}$ & $\begin{array}{l}0.138 * \\
(0.011)\end{array}$ \\
\hline Age & & \\
\hline Over 21 to 25 & $\begin{array}{l}0.346^{*} \\
(0.020)\end{array}$ & $\begin{array}{l}0.353 * \\
(0.020)\end{array}$ \\
\hline Over 25 to 30 & $\begin{array}{l}0.484 * \\
(0.020)\end{array}$ & $\begin{array}{l}0.494 * \\
(0.020)\end{array}$ \\
\hline Over 30 to 35 & $\begin{array}{l}0.556^{*} \\
(0.020)\end{array}$ & $\begin{array}{l}0.567 * \\
(0.020)\end{array}$ \\
\hline Over 35 to 40 & $\begin{array}{l}0.578 * \\
(0.020)\end{array}$ & $\begin{array}{l}0.589 * \\
(0.020)\end{array}$ \\
\hline Over 40 to 45 & $\begin{array}{l}0.574 * \\
(0.020)\end{array}$ & $\begin{array}{l}0.586^{*} \\
(0.019)\end{array}$ \\
\hline Over 45 to 50 & $\begin{array}{l}0.577 * \\
(0.020)\end{array}$ & $\begin{array}{l}0.590^{*} \\
(0.020)\end{array}$ \\
\hline Over 50 to 55 & $\begin{array}{l}0.541 * \\
(0.020)\end{array}$ & $\begin{array}{l}0.551^{*} \\
(0.020)\end{array}$ \\
\hline Over 55 to 60 & $\begin{array}{l}0.474 * \\
(0.020)\end{array}$ & $\begin{array}{l}0.468 * \\
(0.020)\end{array}$ \\
\hline Over 60 to 65 & $\begin{array}{l}0.401 * \\
(0.022)\end{array}$ & $\begin{array}{l}0.408 * \\
(0.021)\end{array}$ \\
\hline Job held over 1 year & $\begin{array}{l}-0.007 \\
(0.008)\end{array}$ & $\begin{array}{l}-0.009 \\
(0.008)\end{array}$ \\
\hline Constant & $\begin{array}{l}1.314 * \\
(0.048)\end{array}$ & $\begin{array}{l}1.354 * \\
(0.047)\end{array}$ \\
\hline $\begin{array}{l}\text { Occupational, industry, and } \\
\text { area dummies }\end{array}$ & Yes & Yes \\
\hline
\end{tabular}

NOTE. Standard errors are in parenthesis. Sample size is 19,677 workers.

* Statistically significant at the 0.01 level (two-tailed test).

** Statistically significant at the 0.05 level (two-tailed test). 


\section{Conclusions}

Overtime regulation in the United States labour market sets the overtime premium at 1.5 times the straight-time hourly wage rate. In the unregulated British labour market, the average premium is 1.4. Surprisingly, the average and marginal premiums in Britain do not vary by length of weekly overtime hours. We provide a simple explanation of this finding in Section 6. Our British results also reveal that the straight time wage is negatively related to both the incidence of overtime and the number of overtime hours worked. This contrasts with U.S. findings of a predominant substitution effect.

The evidence is strong that collective bargaining in Britain is associated with reduced straight-time weekly hours and increased overtime hours. Again this contrasts markedly with the U.S. where unionisation serves to reduce the average number of weekly overtime hours. While somewhat weaker, there is also evidence that British workers covered by collective agreements receive lower average premiums than their uncovered counterparts. The net outcome appears to be that overtime working exerts little impact on covered/uncovered earnings differentials. At least in this last respect, British and U.S. evidence corresponds. 


\section{References}

Bell, D N F and R A Hart (1998), "Working time in Great Britain, 1975-1998: evidence from the New Earnings Survey panel”, Journal of the Royal Statistical Society (Series A), $161,327-48$.

Bell, D N F and R A Hart (1999), "Unpaid work”, Economica (forthcoming).

Bell, D N F, R A Hart, O H bler and W Schwerdt (1999), "Labour market adjustment on the intensive margin: a comparative study of Germany and the UK", University of Stirling (mimeo).

Bils, M (1987) "The cyclical behaviour of marginal cost and price", American Economic Review, 77, 838-55.

Brown, C V, E Levin, J Rosa, R J Ruffell and D T Ulph (1986), "Payment systems, demand constraints and their implications for research into labour supply”, in R Blundell and I Walker (eds.), Unemployment, search and labour supply, pp 190-216, Cambridge: Cambridge University Press.

Calmfors, L and M Hoel (1988), "Work sharing and overtime", Scandinavian Journal of Economics, 90, 45-62.

Ehrenberg, R G, Fringe benefits and overtime behaviour, 1971, Lexington Mass.: Heath.

Hamermesh, D S (1993), Labor demand, Princeton NJ: Princeton University Press.

Hart, R A and J Ruffell (1992), "Costs, efficiency and labour demand", Department of Economics, University of Stirling, (mimeo).

Hart, R A and J Ruffell (1993) "The cost of overtime hours in British production industries", Economica, 60, 183-201.

Income Data Services (1997), Overtime, Study 671, London: Income Data Services Ltd.

Killingsworth, M R (1983), Labor supply, Cambridge: Cambridge University Press.

McDonald, J F and R A Moffitt (1980), "The uses of Tobit analysis", Review of Economics and Statistics, 62, 318-21.

Santamäki-Vuori, T (1986), Cyclical adjustment of hours and employment, Helsinki: Helsinki School of Economics.

Shapiro, M D (1986), “The dynamic demand for capital and labor”, Quarterly Journal of Economics, 101, 513-42.

Trejo, S J (1993), "Overtime pay, overtime hours, and labor unions", Journal of Labor Economics, 11, 253-78. 